\title{
Kallmann syndrome
}

The Kallmann syndrome (KS) combines hypogonadotropic hypogonadism (HH) with anosmia. This is a clinically and genetically heterogeneous disease. $K A L 1$, encoding the extracellular glycoprotein anosmin-1, is responsible for the $X$ chromosome-linked recessive form of the disease. Mutations in FGFR1 or FGF8, encoding fibroblast growth factor receptor-1 and fibroblast growth factor-8, respectively, underlie an autosomal dominant form with incomplete penetrance. Finally, mutations in PROKR2 and PROK2, encoding prokineticin receptor- 2 and prokineticin-2, have been found in heterozygous, homozygous, and compound heterozygous states. These two genes are likely to be involved both in monogenic recessive and digenic/oligogenic KS transmission modes. Notably, mutations in any of the above-mentioned KS genes have been found in less than $30 \%$ of the KS patients, which indicates that other genes involved in the disease remain to be discovered.

\section{In brief}

- KS is a genetically heterogeneous developmental disease that most often manifests as absent spontaneous puberty combined with a defective sense of smell (hyposmia or anosmia).

- Some non-reproductive non-olfactory anomalies can also be present, depending on the genetic form of the disease.

- Disease prevalence has been roughly estimated at 1:8000 males and 1:40000 females, but might be underestimated especially in females.

- Main differential diagnoses are normosmic idiopathic hypogonadotropic hypogonadism and CHARGE syndrome.

- Different modes of KS transmission include X chromosome-linked recessive, autosomal recessive, autosomal dominant with incomplete penetrance, and most probably digenic/oligogenic inheritance.
- Mutations in any of the five known disease genes (KAL1, FGFR1, FGF8, PROKR2, PROK2) have been identified in a relatively small proportion (less than $30 \%$ ) of the patients.

- As many as $30 \%$ of the mutations found in FGFR1 might be de novo mutations, certainly a possibility to be considered before assessing recurrence risk of this genetic form in a family.

- Genetic testing strategy (Figure 1) is based on patient's gender, familial history (if any) and putative mode of disease inheritance, and the presence of additional clinical anomalies that may direct the geneticist towards a particular disease gene or occasionally a contiguous gene syndrome.

- Treatment of KS is that of the hypogonadism. There is currently no treatment for olfactory deficit. In both sexes, hormone replacement therapies are used to stimulate the development of secondary sexual characteristics at the time of puberty, and later to induce fertility.

\footnotetext{
Catherine Dodék, and Jean-Pierre Hardelin ${ }^{*, 2}$

IInserm U567, Département de Génétique et Développement, Institut Cochin, Paris, France; ${ }^{2}$ Inserm U587, Département de Neuroscience, Institut Pasteur, Paris, France
}

European Journal of Human Genetics (2009) 17, 139-146;

doi:10.1038/ejhg.2008.206; published online 5 November 2008

Keywords: Kallmann syndrome; KAL1; FGFR1; FGF8; PROKR2; PROK2

*Correspondence: $\operatorname{Dr} C$ Dodé, Département de génétique et développement, Institut Cochin, 24 rue du Faubourg Saint Jacques, Paris 75014, France. Tel: + 331444124 83; Fax: + 3315841 15 80; E-mail: catherine.dode@inserm.fr

or Dr J-P Hardelin, Inserm U587, Institut Pasteur, 25 rue du Dr Roux, Paris 75015, France. Tel: + 331456888 91; Fax: + 331406134 42;

E-mail: jean-pierre.hardelin@pasteur.fr

Received 29 May 2008; revised 8 September 2008; accepted 1 October 2008; published online 5 November 2008

\section{Introduction}

Maestre de San Juan was probably the first to report, in 1856 , the association of the absence of olfactory structures in the brain and the presence of small testes in an individual. ${ }^{1}$ The syndrome was identified as a clinical entity in 1944 by an American medical geneticist, Kallmann, who carried out a study on the occurrence of hypogonadism accompanied by anosmia in three affected families. ${ }^{2}$ He showed the cosegregation of the anosmia and the hypogonadism in all the affected individuals, and therefore established that this syndrome can be hereditary. In the 1950s, the Swiss anatomist de Morsier further documented the disease by describing the underdevelopment or absence of the olfactory bulbs and tracts in several 
male patients with hypogonadism. ${ }^{3}$ Some years later, the hypogonadism was ascribed to gonadotropin-releasing hormone (GnRH) deficiency. ${ }^{4}$

The prevalence of KS is still unknown. It has been roughly estimated at one out of 8000 in boys. In girls, the prevalence is thought to be five times lower, but is probably underestimated because some affected females only have mild hypogonadism (see below). Moreover, primary amenorrhea in females often remains unexplored.

\section{Clinical overview}

The Kallmann syndrome typically combines severe $\mathrm{HH}$ with a complete absence of the sense of smell (anosmia). The degree of the hypogonadism and that of the smell deficiency can, however, vary significantly, not only between unrelated patients, but also within affected families $^{5,6}$ (and see pedigrees in references ${ }^{7-14}$ ), even between monozygotic twins. ${ }^{15,16}$ In some families, both typical KS phenotypes and dissociated phenotypes with either hypogonadism or anosmia have been described. $^{7,10,13,14,17}$ In addition, apparent reversal of the hypogonadism after discontinuation of hormonal treatment has been reported in a few KS patients. ${ }^{9,18,19}$ Finally, a variety of non-reproductive non-olfactory additional anomalies are present in only a fraction of KS patients. These disorders include involuntary upper limb mirror movements (bimanual synkinesis), ${ }^{17,20-22}$ abnormal eye movements, ${ }^{21,23}$ congenital ptosis, ${ }^{24,25}$ abnormal visual spatial attention, ${ }^{26}$ hearing impairment, ${ }^{5,6,8,27-29}$ agenesis of the corpus callosum, ${ }^{7,13}$ unilateral (occasionally bilateral) renal agenesis, ${ }^{30-32}$ cleft lip or palate, ${ }^{5-7,33}$ agenesis of one or several teeth (hypodontia), ${ }^{7,24,33,34}$ obesity $^{6,10}$ and other less documented anomalies (see reference ${ }^{35}$ for review).

\section{Differential diagnosis: normosmic idiopathic $\mathrm{HH}$ and CHARGE syndrome}

Difficulties are encountered at both ends of KS phenotypic spectrum that is either in the absence of a conspicuous smell deficiency or when non-reproductive non-olfactory additional anomalies are present on top of a typical KS (see Figure 1).

Given the variable degree of hyposmia in $\mathrm{KS}$, the distinction between KS and normosmic idiopathic $\mathrm{HH}$ (nIHH) is currently unclear, especially as $\mathrm{HH}$ patients do not always undergo detailed olfactory testing. There is genetic evidence, however, to suggest that nIHH and KS represent distinct nosological entities. Indeed, the genes encoding GnRH and kisspeptin receptors that are involved in $\mathrm{nIHH}^{37-39}$ do not seem to be required for the embryonic migration of neuroendocrine GnRH cells, the process likely to be defective in KS patients (see below). Large scale genetic testing of genuine $\mathrm{nIHH}$ cases for the presence of mutations in KS genes should help to clarify this issue. The recent report of a family in which deleterious GNRHR and FGFR1 missense mutations cosegregated in the nIHH individuals indicates, however, that the situation could be more complicated than anticipated. ${ }^{40}$

CHARGE syndrome has an estimated birth incidence of 1 in 8500-12000. The defining features that make the acronym are coloboma, heart anomalies, choanal atresia, retardation of growth and/or development, genital and ear anomalies. However, no single feature is universally present or sufficient for the diagnosis of CHARGE syndrome. Other frequently occurring features include characteristic face and hand dysmorphia, hypotonia, arhinencephaly, semicircular canal agenesis or hypoplasia, hearing impairment, urinary tract anomalies, orofacial clefting, dysphagia, and tracheo-oesophagial anomalies. New diagnostic criteria have been proposed in the past few years (see reference ${ }^{41}$ ). Moreover, it has been reported that most if not all CHARGE patients have both olfactory bulb aplasia or hypoplasia and $\mathrm{HH}^{42,43}$ that is, the two KS defining features. Consequently, previously reported KS cases associated with congenital heart disease ${ }^{44}$ or choanal atresia $^{45}$ could in fact represent unrecognised mild CHARGE cases. ${ }^{46}$ CHARGE syndrome shares additional traits with the KAL2 genetic form of KS (see below), including cleft lip or palate, present in $20-35 \%$ of $\mathrm{KAL}^{7,11-13}$ and $\mathrm{CHARGE}^{47}$ patients, external ear malformation, noted in virtually all CHARGE patients ${ }^{47}$ and a few KAL2 patients, ${ }^{48}$ agenesis of the corpus callosum, reported in several CHARGE ${ }^{47}$ and KAL2 patients, ${ }^{7,13}$ and coloboma that is highly prevalent in CHARGE patients ${ }^{47}$ and has been reported in at least one KAL2 patient too. ${ }^{7}$ Most individuals with CHARGE syndrome are heterozygous for loss-of-function mutations in CHD7 that encodes a chromodomain (chromatin organisation modifier domain) helicase DNA-binding protein. ${ }^{49,50}$ Because of the similarity between CHARGE and KAL2 phenotypes, it is tempting to speculate that there are functional interactions between CHD7 and the FGFR1-signalling pathway.

\section{Diagnostic approaches}

Most cases are diagnosed at the time of puberty because of the lack of sexual development, identified by small testes and absent virilisation in males or the lack of breast development and primary amenorrhea in females. KS is diagnosed when low serum gonadotropins and gonadal steroids are coupled with a compromised sense of smell. The latter should be ascertained by means of detailed questioning and olfactory screening tests, ${ }^{51-54}$ because it is rarely mentioned spontaneously. Magnetic resonance imaging (MRI) of the forebrain can be carried out to show the hypoplasia or aplasia of the olfactory bulbs and tracts ${ }^{55}$ (Figure 2). MRI is also useful to exclude hypothalamic or 


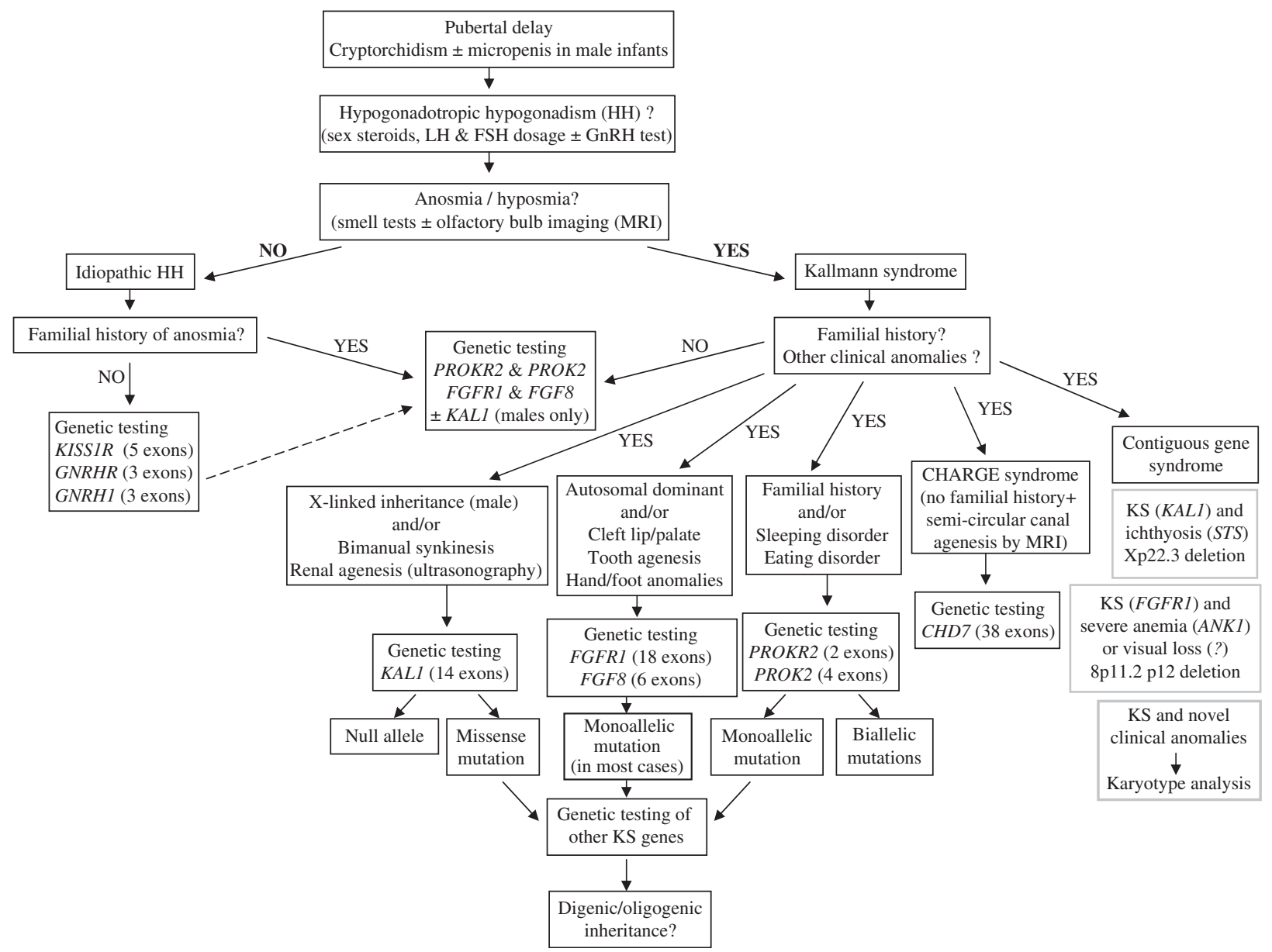

Figure 1 Genetic testing strategy for Kallmann syndrome. The strategy is based on patient's gender, familial history (if any) and putative mode of disease inheritance, and the presence of additional clinical anomalies that may direct the geneticist towards a particular disease gene or, occasionally, a contiguous gene syndrome at Xp22.3 $3^{36}$ or $8 \mathrm{p} 11.2 \mathrm{p} 12 .^{7}$ The search for KAL1 mutations is restricted to affected males, either isolated cases or patients with a familial history compatible with X-linked recessive mode of inheritance. Mutation screening of the known KS genes (KAL1, FGFR1, FGF8, PROKR2, PROK2) leads to the identification of a mutation in less than one-third of the patients. Notably, as many as $30 \%$ of the mutations found in FGFR1 might be de novo mutations, certainly a possibility to be considered before assessing recurrence risk of this genetic form in a family. The main differential diagnoses of KS are normosmic idiopathic hypogonadotropic hypogonadism and CHARGE syndrome.

pituitary lesions as the cause of HH. ${ }^{56}$ The GnRH deficiency can be indirectly assessed by means of endocrinological tests (see reference ${ }^{57}$ ).

Notably, KS may also be suspected as early as in infancy in boys, in the presence of cryptorchidism or a micropenis, combined with subnormal LH and FSH concentrations. Indeed, the postnatal surge in $\mathrm{FSH}, \mathrm{LH}$, and testosterone in the male infant as a consequence of the continued function of the fetal GnRH pulse generator provides a 6month window of opportunity to establish the diagnosis of $\mathrm{HH}^{58}$ and alert the clinician to the possibility of its association with olfactory impairment. In this respect, the usefulness of forebrain MRI in diagnosing the disease in children too young to undergo meaningful testing of olfaction or of the hypothalamo-pituitary-gonadal axis should be emphasised, ${ }^{59,60}$ even though normal olfactory bulb images have been reported in a few KS patients. ${ }^{22,29}$
Finally, the presence of non-reproductive non-olfactory additional disorders, including mirror movements, palate anomalies, renal agenesis (ultrasonography), hearing impairment (audiometric testing), and tooth agenesis, should be carefully searched in the patients and, whenever possible, their first-degree relatives, because such anomalies can direct the geneticist towards particular genetic forms of the disease (see below and Figure 1). In KS-affected families, the cleft palate or renal agenesis diagnosed by means of fetal ultrasonography may occasionally reveal the disease before birth.

\section{The complex genetics of $\mathrm{KS}$}

Although most KS patients present as sporadic cases, many cases are clearly familial, with three modes of inheritance 

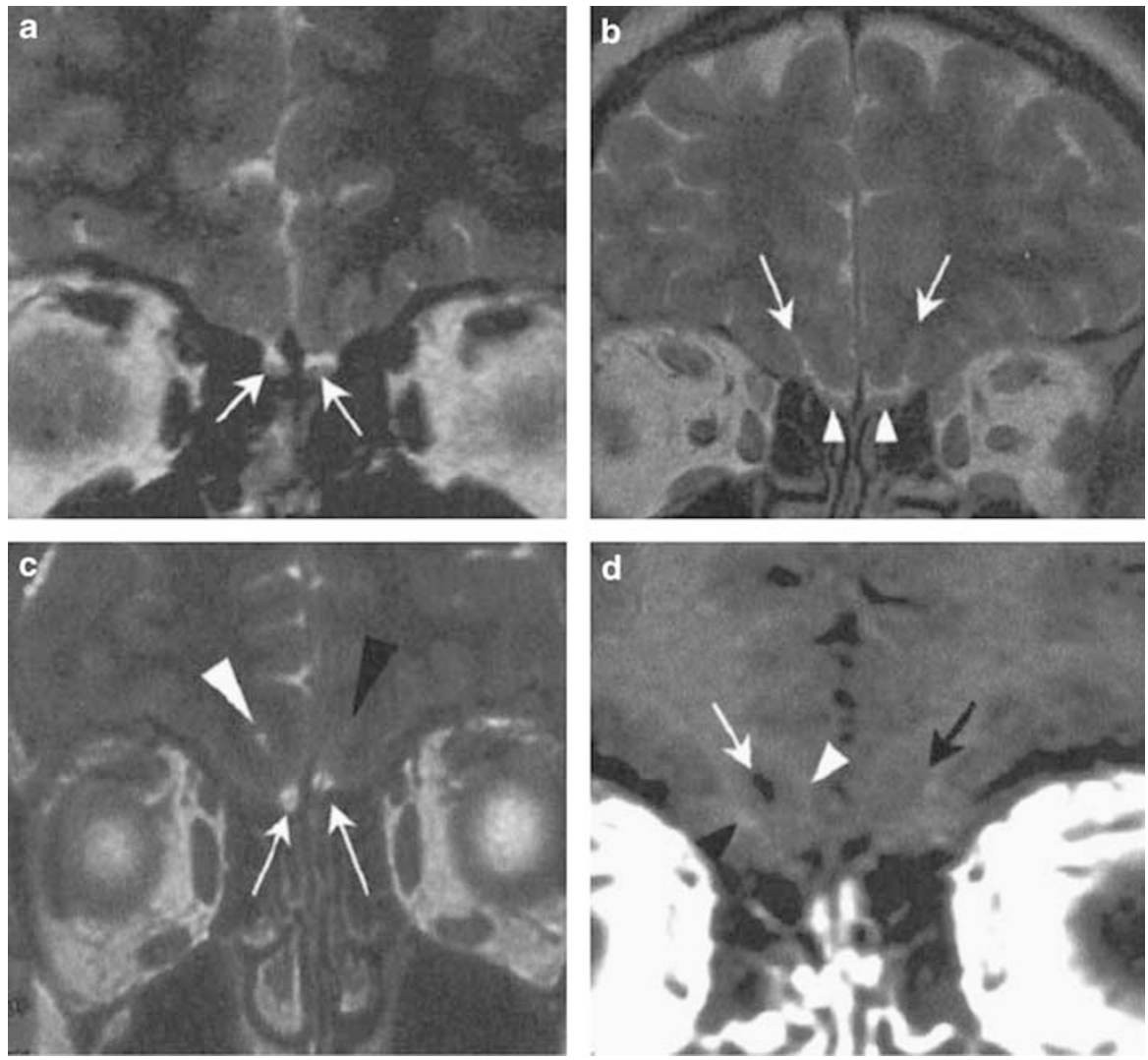

Figure 2 Cranial magnetic resonance imaging (MRI) of the olfactory bulb region in a control man (a and $\mathbf{b}$ ) and a man affected by Kallmann syndrome (c and $\mathbf{d}$ ). ( $(\mathbf{a}$ and $\mathbf{b})$ MRI T2-weighted sequence in coronal plane shows normal olfactory bulbs in the control individual (a, white arrows), and posterior to the olfactory bulbs, good differentiation of the rhinal sulci (b, white arrows) and olfactory tracts (b, white arrowheads). (c) MRI T2weighted sequence in coronal plane shows very small olfactory bulbs in the KS patient (white arrows). On the right side, the rhinal sulcus (white arrowhead) is visible, with good differentiation between the right gyrus and orbital gyrus. On the left side, there is no rhinal sulcus (black arrowhead), and no differentiation between the right and orbital gyri. (d) MRI T1-weighted sequence in coronal plane, posterior to olfactory bulbs, confirms the presence of the rhinal sulcus on the right side (white arrow), with a relatively good differentiation between the right (white arrowhead) and orbital (black arrowhead) gyri, and the absence of the rhinal sulcus on the left side (black arrow).

being reported: $\mathrm{X}$ chromosome-linked recessive (OMIM no. 308700), autosomal dominant (OMIM no. 147950), and autosomal recessive (OMIM no. 244200) (http://www.ncbi.nlm.nih.gov/omim/). In the autosomal dominant form, incomplete penetrance has been emphasized. ${ }^{5,61}$

Five causal genes have been identified to date, namely, by chronological order of discovery, KAL1, ${ }^{62-64}$ FGFR $1{ }^{7}$ PROKR2 and PROK2, ${ }^{10}$ and FGF8 ${ }^{65}$ Various loss-of-function mutations in $K A L 1$, encoding the extracellular matrix glycoprotein anosmin-1, and in FGFR1 or FGF8, encoding fibroblast growth factor receptor-1 and fibroblast growth factor- 8 , underlie the $\mathrm{X}$ chromosome-linked form (KAL1) and an autosomal dominant form (KAL2) of KS, respectively (see Supplementary Tables S1, S2 and S3 for a list of the mutations). The KAL1 and KAL2 genetic forms account for roughly $8 \%$ and $10 \%$ of all KS cases, respectively. Mutations in KAL1 are mainly nonsense mutations, frameshift mutations, or large gene deletions, whereas the majority of mutations in FGFR1 (ie, approximately 70\%) or FGF8 (all six mutations reported so far) are missense mutations. Notably, as many as $30 \%$ of the FGFR 1 mutations found in the patients could be de novo mutations ${ }^{13,48,66}$ (C Dodé, unpublished results). Putative lossof-function mutations in PROKR2 or PROK2, encoding prokineticin receptor-2 and prokineticin-2, respectively, have been detected in approximately $9 \%$ of the KS patients (see Supplementary Table S4 for a list of the mutations). Most of these mutations are missense mutations, and many have also been found in apparently unaffected individuals, thus raising questions regarding their pathogenic role in the disease. Deleterious effects on prokineticin signalling, however, have subsequently been shown in vitro for nearly all the missense mutations. ${ }^{67,68}$ The finding, for given PROKR2 and PROK2 mutations, of both heterozygous and homozygous (or compound heterozygous) unrelated patients $^{10,69}$ is quite remarkable, and argues in favour of a digenic or oligogenic mode of inheritance in heterozygous 
patients. To date, digenic inheritance of KS has been shown in three such patients, who had monoallelic missense mutations both in PROKR2 and PROK $2,{ }^{67}$ FGFR1 (C Dodé, unpublished), or $K A L 1 .{ }^{10}$ It is tempting to speculate that the latter patient bears a hypomorphic KAL1 allele encoding a protein variant that would still retain some biological activity, whereas the vast majority of the KAL1 mutations reported so far lead to null alleles that are apparently sufficient to produce the abnormal phenotype in males. Other patients carrying heterozygous mutations in PROKR2, PROK2, or hypomorphic mutations in KAL1 are expected to carry additional mutations in other, as yet unknown, KS genes. Indeed, mutations in the five known genes together account for less than 30\% of KS cases, indicating that other genes responsible for the disease remain to be discovered, some of which might also be involved in FGF signalling or prokineticin signalling. Notably, recent evidence indicates that oligogenic mode of inheritance may also apply to patients carrying mutations in FGFR1 or FGF8. Three patients carrying missense mutations in FGFR1 have indeed been found to also have a monoallelic or a biallelic mutation in $F G F 8,{ }^{64}$ or a monoallelic mutation in PROKR2 (see above).

\section{Genotype-phenotype correlation}

For each genetic form of KS identified so far, the clinical heterogeneity of the disease within affected families clearly indicates that the manifestation of KS phenotypes is dependent on factors other than the mutated gene itself. These factors probably include epigenetic factors and modifier genes, both of which have not yet been identified. In addition, digenic or oligogenic inheritance presumably accounts in part for the long recognised incomplete penetrance of the disease. That said, some general features have emerged from clinical observations in the patients affected by the different genetic forms of KS. For instance, a greater variability in the degree of hypogonadism has been observed in patients carrying mutations in FGFR1, FGF8, PROKR2, or PROK2, than in KAL1 patients. ${ }^{7,10,65,70-72}$ In particular, spontaneously fertile individuals carrying mutations in any of the four autosomal KS genes account for the transmission of the disease over several generations, whereas the X-linked form of KS is usually transmitted by the female carriers of KAL1 mutations, who are clinically unaffected. Among the variety of non-reproductive and non-olfactory disorders that affect a fraction of the KS patients, some have been reported for specific genetic forms of the disease. For instance, unilateral renal agenesis occurs in approximately $30 \%$ of KAL1 patients, ${ }^{31,32}$ but has so far not been reported in patients with FGFR1, FGF8, PROKR2, or PROK2 mutations. On the other hand, the loss of nasal cartilage, external ear hypoplasia, and skeletal anomalies of the hands or feet, have only been reported in KAL2 patients. ${ }^{7,13,48}$ By contrast, hearing impairment is
Table 1 A clinical comparison between KAL1 and KAL2 genetic forms of Kallmann syndrome

\begin{tabular}{|c|c|c|}
\hline Genetic form & KAL1 & KAL2 \\
\hline Gene (location) & KAL1 (Xp22.3) & FGFR1 (8p12) \\
\hline $\begin{array}{l}\text { Mode of } \\
\text { transmission }\end{array}$ & $\begin{array}{l}\text { X chromosome- } \\
\text { linked }\end{array}$ & $\begin{array}{l}\text { Autosomal dominant } \\
\text { (incomplete } \\
\text { penetrance) }\end{array}$ \\
\hline Smell deficiency & $\begin{array}{l}\text { Hyposmia to } \\
\text { anosmia }\end{array}$ & None to anosmia \\
\hline Hypogonadism & Usually severe & Highly variable \\
\hline \multicolumn{3}{|c|}{ Non-reproductive and non-olfactory anomalies } \\
\hline $\begin{array}{l}\text { Bimanual } \\
\text { synkinesis }\end{array}$ & Yes $(>75 \%)$ & Uncommon \\
\hline Renal agenesis & Yes $(30 \%)$ & Not reported \\
\hline Cleft lip/palate & $\begin{array}{l}\text { No, but high } \\
\text { arched palate }\end{array}$ & Yes $(25-30 \%)$ \\
\hline Tooth agenesis & Yes & Yes (frequent?) \\
\hline $\begin{array}{l}\text { Hearing } \\
\text { impairment }\end{array}$ & $\begin{array}{l}\text { Yes (unknown } \\
\text { frequency) }\end{array}$ & $\begin{array}{l}\text { Yes (unknown } \\
\text { frequency) }\end{array}$ \\
\hline Other anomalies & Pes cavus, ptosis & $\begin{array}{l}\text { Corpus callosum } \\
\text { agenesis, external ear } \\
\text { hypoplasia, absent } \\
\text { nasal cartilage, hand/ } \\
\text { foot skeletal } \\
\text { anomalies, iris } \\
\text { coloboma }\end{array}$ \\
\hline
\end{tabular}

common to several genetic forms of $\mathrm{KS},{ }^{7,8,13,23,24,29,65}$ although it should be noted that the underlying defect (conductive, perceptive, or mixed) is likely to vary between different genetic forms. Palate defects should also be considered as one of these shared traits, even though the severity differs between KAL1 (high arched palate) and KAL2 (cleft palate). The cleft lip and/or palate may occur in as many as $25-30 \%$ of the KAL2 cases. ${ }^{7,11-13,65,73}$ Lastly, bimanual synkinesis is highly prevalent in KAL1 (maybe $>75 \%$ of the cases), ${ }^{17,22}$ but seems to be much less common in KAL2.7,12 Table 1 displays a comparison between KAL1 and KAL2 clinical features. Additional anomalies have so far not been reported in KS patients carrying mutations in PROKR2 or PROK2, with the notable exception of a severe sleep disorder and marked obesity in one patient, ${ }^{10}$ which could be related to the known function of prokineticin-2 signalling in behavioural circadian rhythms, including sleep-wake and ingestive behaviour. ${ }^{74}$ The prevalence of sleeping and eating disorders in KS patients, however, remains to be determined.

\section{Treatment of the hypogonadism}

The treatment of hypogonadism in KS aims first to initiate virilisation or breast development, and second to develop fertility. Hormone replacement therapy, usually with testosterone for males and combined oestrogen and progesterone 
for females, is the treatment to stimulate the development of secondary sexual characteristics. For those desiring fertility, either gonadotropins or pulsatile GnRH can be used to obtain testicular growth and sperm production in males or ovulation in females. Both treatments restore fertility in a vast majority of affected individuals. ${ }^{75}$ It is still unknown whether transient hormone replacement therapy in affected male infants to simulate the postnatal surge in gonadotropins could have later impact on their sexual life and reproductive prognosis (see reference ${ }^{58}$ ).

\section{Pathophysiology}

Most phenotypic anomalies reported in KS may result from the developmental failures during the organogenesis period, between 4 and 10 embryonic weeks (see reference ${ }^{76}$ for review). The developmental disorder leading to the absence (or hypoplasia) of the olfactory bulbs and tracts, and to anosmia in KS is not completely understood. It may involve a failure of the terminal elongation or targeting of olfactory axons, a primary morphogenetic defect of the olfactory bulbs (at the end of the 6th embryonic week), and a later defect in axonal branching of the olfactory bulb output neurons. In the late 1980s, new light was shed on the mechanism of the GnRH deficiency underlying KS hypogonadism, with the discovery of a close topographic link between the peripheral olfactory system and neuroendocrine GnRH cells during the embryonic life. These cells undergo a migration, beginning in the 6th embryonic week, from the olfactory epithelium to the forebrain along the olfactory nerve pathway. ${ }^{77}$ In a human fetus carrying a chromosomal deletion at Xp22.3 that included KAL1, it was shown that GnRH cells had not migrated normally and had accumulated in the upper nasal region. ${ }^{78}$ There are presently no pathohistological data to verify that the embryonic migration of GnRH cells is arrested in individuals affected by other genetic forms of KS. In Prokr2 or Prok2 homozygous knockout mice, and mice carrying Fgfr1 or Fgf8 hypomorphic mutations in the homozygous state, however, the migration of these cells is disrupted too. ${ }^{14,65,79,80}$ The mechanism of the putative defect of $\mathrm{GnRH}$ cell migration in KS is still conjectural. It could be either a consequence of the early degeneration of olfactory nerve and terminal nerve axons, which act as guiding cues, or a process directly affecting the GnRH cells themselves. Moreover, defects in GnRH cell fate specification, differentiation, axon elongation, or axon targeting to the hypothalamus median eminence may also contribute to the GnRH deficiency, at least in the KAL2 genetic form of the disease (see reference ${ }^{35,80}$ ).

\section{Unresolved questions}

Although KS was identified as a hereditary disease more than 60 years ago, its genetics is still incompletely under- stood, including its much higher prevalence in males than in females. Among many unresolved genetic and clinical questions are the following:

1. What is the actual prevalence of $\mathrm{KS}$, especially in females?

2. What is the KS phenotypic spectrum, especially with respect to non-reproductive non-olfactory additional disorders?

3. Is hereditary anosmia without apparent hypogonadism a clinical form of KS?

4. Where is the nosological frontier between $\mathrm{KS}$ and normosmic $\mathrm{HH}$ ?

5. How many different disease genes are involved in KS, and how do they functionally interact in the development of olfactory and GnRH neuroendocrine systems (see reference ${ }^{81}$ for current hypotheses)?

6. What is the prevalence of the digenic/oligogenic mode of inheritance among KS patients? Indeed, answer to this question is a prerequisite to assess disease recurrence risk in the affected families.

7. Why is KS more frequent in males than in females?

Given that the X-linked recessive form does not account for the higher disease prevalence in males, could it be that females are to some extent protected against disease occurrence by physiologically higher levels of KAL1 expression during the embryonic life compared to males (because KAL1 partially escapes the $\mathrm{X}$-chromosome inactivation process in humans $\left.{ }^{62}\right)$ ?

\section{References}

1 Maestre de San Juan A: Falta total de los nervios olfactorios con anosmía en un individuo en quien existía una atrofía congénita de los testículos y miembro viril. Siglo Medico 1856; 131: 211.

2 Kallmann FJ, Schoenfeld WA, Barrera SE: The genetic aspects of primary eunuchoidism. Am J Mental Deficiency 1944; XLVIII: 203-236.

3 de Morsier G, Gauthier G: La dysplasie olfacto-génitale. Pathol Biol 1963; 11: 1267-1272.

4 Naftolin F, Harris GW, Bobrow M: Effect of purified luteinizing hormone releasing factor on normal and hypogonadotropic anosmic men. Nature 1971; 232: 496-497.

5 Santen RJ, Paulsen CA: Hypogonadotropic eunuchoidism. I. Clinical study of the mode of inheritance. J Clin Endocrinol Metab 1972; 36: $47-54$.

6 Lieblich JM, Rogol AD, White BJ, Rosen SW: Syndrome of anosmia with hypogonadotropic hypogonadism (Kallmann syndrome). Am J Med 1982; 73: 506-519.

7 Dodé C, Levilliers J, Dupont J-M et al: Loss-of-function mutations in FGFR1 cause autosomal dominant Kallmann syndrome. Nat Genet 2003; 33: 463-465.

8 Massin N, Pêcheux C, Eloit C et al: X chromosome-linked Kallmann syndrome: clinical heterogeneity in three siblings carrying an intragenic deletion of the KAL-1 gene. J Clin Endocrinol Metab 2003; 88: 2003-2008.

9 Pitteloud N, Acierno J, Meysing A, Dwyer A, Hayes F, Crowley W: Reversible Kallmann syndrome, delayed puberty, and isolated anosmia occurring in a single family with a mutation in the FGFR1 gene. J Clin Endocrinol Metab 2005; 90: 1317-1322. 
10 Dodé C, Teixeira L, Levilliers J et al: Kallmann syndrome: mutations in the genes encoding prokineticin- 2 and prokineticin receptor-2. PLoS Genetics 2006; 2: 1648-1652.

11 Pitteloud N, Acierno Jr JS, Meysing A et al: Mutations in fibroblast growth factor receptor 1 cause both Kallmann syndrome and normosmic idiopathic hypogonadotropic hypogonadism. Proc Natl Acad Sci USA 2006; 103: 6281-6286.

12 Trarbach EB, Costa EM, Versiani B et al: Novel fibroblast growth factor receptor 1 mutations in patients with congenital hypogonadotropic hypogonadism with and without anosmia. J Clin Endocrinol Metab 2006; 91: 4006-4012.

13 Dodé C, Fouveaut C, Mortier G et al: Novel FGFR1 sequence variants in Kallmann syndrome, and genetic evidence that the FGFR1c isoform is required in olfactory bulb and palate morphogenesis. Hum Mutat 2007; 28: 97-98.

14 Pitteloud N, Zhang C, Pignatelli D et al: Loss-of-function mutation in the prokineticin 2 gene causes Kallmann syndrome and normosmic idiopathic hypogonadotropic hypogonadism. Proc Natl Acad Sci USA 2007; 104: 17447-17452.

15 Hermanussen M, Sippell WG: Heterogeneity of Kallmann's syndrome. Clin Genet 1985; 28: 106-111.

16 Hipkin L, Casson I, Davis J: Identical twins discordant for Kallmann's syndrome. J Med Genet 1990; 27: 198-199.

17 Quinton R, Duke VM, Robertson A et al: Idiopathic gonadotrophin deficiency: genetic questions addressed through phenotypic characterization. Clin Endocrinol (Oxf) 2001; 55: 163-174.

18 Ribeiro RS, Vieira TC, Abucham J: Reversible Kallmann syndrome: report of the first case with a KAL1 mutation and literature review. Eur J Endocrinol 2007; 156: 285-290.

19 Raivio T, Falardeau J, Dwyer A et al: Reversal of idiopathic hypogonadotropic hypogonadism. N Engl J Med 2007; 357: $863-873$.

20 Conrad B, Kriebel J, Hetzel WD: Hereditary bimanual synkinesis combined with hypogonadotropic hypogonadism and anosmia in four brothers. J Neurol 1978; 218: 263-274.

21 Schwankhaus JD, Currie J, Jaffe MJ, Rose SR, Sherins RJ: Neurologic findings in men with isolated hypogonadotropic hypogonadism. Neurology 1989; 39: 223-226.

22 Quinton R, Duke VM, de Zoysa PA et al: The neuroradiology of Kallmann's syndrome: a genotypic and phenotypic analysis. I Clin Endocrinol Metab 1996; 81: 3010-3017.

23 Söderlund D, Canto P, Méndez J: Identification of three novel mutations in the KAL1 gene in patients with Kallmann syndrome. J Clin Endocrinol Metab 2002; 87: 2589-2592.

24 Hardelin J-P, Levilliers J, Young J et al: Xp22.3 deletions in isolated familial Kallmann's syndrome. J Clin Endocrinol Metab 1993; 76: $827-831$

25 Reardon W: Kallmann syndrome presenting as congenital ptosis in brothers. Clin Dysmorphol 2007; 16: 207-208.

26 Kertzman C, Robinson DL, Sherins RJ, Schwankhaus JD, Mc Clurkin JW: Abnormalities in visual spatial attention in men with mirror movements associated with isolated hypogonadotropic hypogonadism. Neurology 1990; 40: 1057-1063.

27 Hill J, Elliott C, Colquhoun I: Audiological, vestibular and radiological abnormalities in Kallmann's syndrome. I Laryngol Otol 1992; 106: 530-534.

28 Coatesworth AP, Woodhead CJ: Conductive hearing loss associated with Kallmann's syndrome. J Laryngol Otol 2002; 116: $125-126$.

29 Sato N, Katsumata N, Kagami M et al: Clinical assessment and mutation analysis of Kallmann syndrome $1(K A L 1)$ and fibroblast growth factor receptor 1 (FGFR1, or KAL2) in five families and 18 sporadic patients. J Clin Endocrinol Metab 2004; 89: $1079-1088$.

30 Wegenke JD, Uehling DT, Wear Jr JB et al: Familial Kallmann syndrome with unilateral renal aplasia. Clin Genet 1975; 7: $368-381$

31 Hardelin J-P, Levilliers J, Blanchard S et al: Heterogeneity in the mutations responsible for $\mathrm{X}$ chromosome-linked Kallmann syndrome. Hum Mol Genet 1993; 2: 373-377.
32 Kirk J, Grant D, Besser G et al: Unilateral renal aplasia in X-linked Kallmann's syndrome. Clin Genet 1994; 46: 260-262.

33 Molsted K, Kjaer I, Giwercman A, Versterhauge S, Skakkebaek N: Craniofacial morphology in patients with Kallmann's syndrome with and without cleft lip and palate. Cleft Palate-Craniofacial J 1997; 34: 417-424.

34 de Zegher F, Lagae L, Declerck D, Vinckier F: Kallmann syndrome and delayed puberty associated with agenesis of lateral maxillary incisors. J Craniofac Genet Dev Biol 1995; 15: 87-89.

35 Tsai P-S, Gill J: Mechanisms of disease: insights into X-linked and autosomal-dominant Kallmann syndrome. Nat Clin Pract Endocrinol Metab 2006; 2: 160-171.

36 Ballabio A, Andria G: Deletions and translocations involving the distal short arm of the human $\mathrm{X}$ chromosome: review and hypotheses. Hum Mol Genet 1992; 1: 221-227.

37 de Roux N, Young J, Misrahi M et al: A family with hypogonadotropic hypogonadism and mutations in the gonadotropin-releasing hormone receptor. N Engl J Med 1997; 337: 1597-15602.

38 de Roux N, Genin E, Carel JC, Matsuda F, Chaussain JL, Milgrom E: Hypogonadotropic hypogonadism due to loss of function of the KiSS1-derived peptide receptor GPR54. Proc Natl Acad Sci USA 2003; 100: 10972-10976.

39 Seminara SB, Messager S, Chatzidaki EE et al: The GPR54 gene as a regulator of puberty. $N$ Engl J Med 2003; 349: 1614-1627.

40 Pitteloud N, Quinton R, Pearce S et al: Digenic mutations account for variable phenotypes in idiopathic hypogonadotropic hypogonadism. J Clin Invest 2007; 117: 457-463.

41 Sanlaville D, Verloes A: CHARGE syndrome: an update. Eur J Hum Genet 2007; 15: 389-399.

42 Pinto G, Abadie V, Mesnage R et al: CHARGE syndrome includes hypogonadotropic hypogonadism and abnormal olfactory bulb development. I Clin Endocrinol Metab 2005; 90: 5621-5626.

43 Blustajn J, Kirsch CF, Panigrahy A, Netchine I: Olfactory anomalies in CHARGE syndrome: imaging findings of a potential major diagnostic criterion. AJNR Am J Neuroradiol 2008; 29: $1266-1269$

44 Cortez AB, Galindo A, Arensman FW, Van Dop C: Congenital heart disease associated with sporadic Kallmann syndrome. Am J Med Genet 1993; 46: 551-554.

45 Klein VR, Friedman JM, Brookshire GS, Brown OE, Edman CD: Kallmann syndrome associated with choanal atresia. Clin Genet 1987; 31: 224-227.

46 Ogata T, Fujiwara I, Ogawa E, Sato N, Udaka T, Kosaki K: Kallmann syndrome phenotype in a female patient with CHARGE syndrome and CHD7 mutation. Endocr J 2006; 53: 741-743.

47 Tellier AL, Cormier-Daire V, Abadie V et al: CHARGE syndrome: report of 47 cases and review. Am J Med Genet 1998; 76: 402-409.

48 Zenaty D, Bretones $\mathrm{P}$, Lambe $\mathrm{C}$ et al: Paediatric phenotype of Kallmann syndrome due to mutations of fibroblast growth factor receptor 1 (FGFR1). Mol Cell Endocrinol 2006; 254-255: 78-83.

49 Vissers LE, van Ravenswaaij CM, Admiraal R et al: Mutations in a new member of the chromodomain gene family cause CHARGE syndrome. Nat Genet 2004; 36: 955-957.

50 Lalani SR, Safiullah AM, Fernbach SD et al: Spectrum of CHD7 mutations in 110 individuals with CHARGE syndrome and genotype-phenotype correlation. Am J Hum Genet 2006; 78: $303-314$.

51 Rosen S, Gann P, Rogol A: Congenital anosmia:detection thresholds for seven odorant classes in hypogonadal and eugonadal patients. Ann Otol Rhinol Laryngol 1979; 88: 288.

52 Doty R, Shaman P, Dann M: Development of the University of Pennsylvania Smell identification Test, a standardized microencapsulated test of olfactory function. Physiol Behav 1984; 32: 489-502.

53 Davidson TM, Murphy C: Rapid clinical evaluation of anosmia. The alcohol sniff test. Arch Otolaryngol Head Neck Surg 1997; 123: 591-594.

54 Chalouhi C, Faulcon P, Le Bihan C, Hertz-Pannier L, Bonfils P, Abadie V: Olfactory evaluation in children: application to the CHARGE syndrome. Pediatrics 2005; 116: e81-e88. 
55 Klingmüller D, Duwes W, Krahe T, Brecht G, Schweikert H-U: Magnetic resonance imaging of the brain in patients with anosmia and hypothalamic hypogonadism (Kallmann's syndrome). J Clin Endocrinol Metab 1987; 65: 581-584.

56 Whitcomb R, Crowley WJ: Male hypogonadotropic hypogonadism. Endocrinol Metab Clin North Am 1993; 22: 125-143.

57 Seminara SB, Hayes FJ, Crowley Jr WF: Gonadotropin-releasing hormone deficiency in the human (idiopathic hypogonadotropic hypogonadism and Kallmann's syndrome): pathophysiological and genetic considerations. Endocr Rev 1998; 19: 521-539.

58 Grumbach MM: A window of opportunity: the diagnosis of gonadotropin deficiency in the male infant. J Clin Endocrinol Metab 2005; 90: 3122-3127.

59 Truwit CL, Barkovich AJ, Grumbach MM, Martini JJ: MR imaging of Kallmann syndrome, a genetic disorder of neuronal migration affecting the olfactory and genital systems. AJNR Am J Neuroradiol 1993; 14: 827-838.

60 Birnbacher R, Wandl-Vergesslich K, Frisch H: Diagnosis of Xrecessive Kallmann syndrome in early infancy. Evidence of hypoplastic rhinencephalon. Eur J Pediatr 1994; 153: 245-247.

61 White BJ, Rogol AD, Brown KS, Lieblich JM, Rosen SW: The syndrome of anosmia with hypogonadotropic hypogonadism: a genetic study of 18 new families and a review. Am J Med Genet 1983; 15: 417-435.

62 Franco B, Guioli S, Pragliola A et al: A gene deleted in Kallmann's syndrome shares homology with neural cell adhesion and axonal path-finding molecules. Nature 1991; 353: 529-536.

63 Legouis R, Hardelin J-P, Levilliers J et al: The candidate gene for the X-linked Kallmann syndrome encodes a protein related to adhesion molecules. Cell 1991; 67: 423-435.

64 Hardelin J-P, Levilliers J, del Castillo I et al: X chromosome-linked Kallmann syndrome: stop mutations validate the candidate gene. Proc Natl Acad Sci USA 1992; 89: 8190-8194.

65 Falardeau J, Chung WC, Beenken A et al: Decreased FGF8 signaling causes deficiency of gonadotropin-releasing hormone in humans and mice. I Clin Invest 2008; 118: 2822-2831.

66 Sato N, Ohyama K, Fukami M, Okada M, Ogata T: Kallmann syndrome: somatic and germline mutations of the fibroblast growth factor receptor 1 gene in a mother and the son. J Clin Endocrinol Metab 2006; 91: 1415-1418.

67 Cole LW, Sidis Y, Zhang C et al: Mutations in prokineticin 2 (PROK2) and PROK2 receptor 2 (PROKR2) in human gonadotrophin-releasing hormone deficiency: molecular genetics and clinical spectrum. J Clin Endocrinol Metab 2008; 93: 3551-3559.

68 Monnier C, Dodé C, Fabre L et al: PROKR2 missense mutations associated with Kallmann syndrome impair receptor signallingactivity. Hum Mol Genet 2008 [Epub ahead of print]. PMID 18826963.
69 Leroy C, Fouveaut C, Leclercq S et al: Biallelic mutations in the prokineticin-2 gene in two sporadic cases of Kallmann syndrome. Eur J Hum Genet 2008; 16: 865-868.

70 Oliveira LM, Seminara SB, Beranova $\mathrm{M}$ et al: The importance of autosomal genes in Kallmann syndrome: genotype-phenotype correlations and neuroendocrine characteristics. J Clin Endocrinol Metab 2001; 86: 1532-1538.

71 Pitteloud N, Meysing A, Quinton R et al: Mutations in fibroblast growth factor receptor 1 cause Kallmann syndrome with a wide spectrum of reproductive phenotypes. Mol Cell Endocrinol 2006; 254-255: 60-69.

72 Salenave S, Chanson P, Bry $\mathrm{H}$ et al: Kallmann's syndrome: a comparison of the reproductive phenotypes in men carrying KAL1 and FGFR1/KAL2 mutations. J Clin Endocrinol Metab 2008; 93: $758-763$.

73 Albuisson J, Pêcheux C, Carel J-C et al: Kallmann syndrome: 14 novel mutations in KAL1 and FGFR1 (KAL2). Hum Mutat 2005; 25: 98-99.

74 Zhou QY, Cheng MY: Prokineticin 2 and circadian clock output. FEBS J 2005; 272: 5703-5709.

75 Buchter D, Behre HM, Kliesch S, Nieschlag E: Pulsatile GnRH or human chorionic gonadotropin/human menopausal gonadotropin as effective treatment for men with hypogonadotropic hypogonadism: a review of 42 cases. Eur J Endocrinol 1998; 139: $298-303$.

76 Hardelin J-P, Dodé C: KAL1, FGFR1, PROKR2, PROK2, and Kallmann syndrome; in: Epstein C, Erickson R, Wynshaw-Boris A (eds): Inborn errors of development. New York: Oxford University Press, 2008, chapter 47, pp 482-490.

77 Schwanzel-Fukuda M, Crossin KL, Pfaff DW, Bouloux PMG, Hardelin J-P, Petit C: Migration of luteinizing hormone-releasing hormone (LHRH) neurons in early human embryos. I Comp Neurol 1996; 366: 547-557.

78 Schwanzel-Fukuda M, Bick D, Pfaff DW: Luteinizing hormonereleasing hormone (LHRH)-expressing cells do not migrate normally in an inherited hypogonadal (Kallmann) syndrome. Mol Brain Res 1989; 6: 311-326.

79 Matsumoto S, Yamazaki C, Masumoto KH et al: Abnormal development of the olfactory bulb and reproductive system in mice lacking prokineticin receptor PKR2. Proc Natl Acad Sci USA 2006; 103: 4140-4145.

80 Chung WC, Moyle SS, Tsai PS: Fibroblast growth factor 8 signaling through Fgf receptor 1 is required for the emergence of gonadotropin-releasing hormone neurons. Endocrinology 2008; 149: 4997-5003.

81 Hardelin J-P, Dodé C: The complex genetics of Kallmann syndrome: KAL1, FGFR1, FGF8, PROKR2, PROK2, et al. Sex Dev 2008; 2: 181-193.

Supplementary Information accompanies the paper on European Journal of Human Genetics website (http://www.nature.com/ejhg) 